\title{
Good Administration as a Fundamental Right
}

\section{Margrét Vala Kristjánsdóttir, Associate Professor at Reykjavík University}

\begin{abstract}
The EU Charter of Fundamental Rights lists good administration as a fundamental right. The scope of this right, as defined in Article 41 of the EU Charter, is limited to situations in which persons are dealing with the institutions and bodies of the European Union; this gives it a narrower scope than that of the Charter as a whole. This paper discusses the status of this right as a subjective, fundamental right and a codified principle of EU law. The focus is on the question of applicability of the right to situations in which persons are dealing with the institutions and bodies of Member States and questions are raised regarding the implications of Article 41 in this respect. The paper concludes that Article 41 of the Charter in fact limits the applicability of good administration to the institutions and bodies of the EU. This does not however, preclude the applicability of a general principle of good administration, as established by the European Court of Justice, to Member States and the formal recognition of this principle in the EU Charter seems to affect legal reasoning and contribute to some extent to the protection of administrative rules in the implementation of EU law.
\end{abstract}

Keywords: Charter of Fundamental Rights. Article 41, Good Administration, Applicability to Member States, General Principle of Good Administration. 


\section{Introduction}

Administrative rules play an important role in the implementation of law, including law regarding the protection of the various fundamental rights. As such, administrative law is an important factor in the protection of rights. The right to be heard and the duty to collect sufficient information may, for instance, be important for the realization of the various rights protected by national legislations and constitutions. These rules may therefore function as means to an end, the end being the attainment of the substantive right in question in a given case.

This is also true for the implementation of the substantive law of the European Union. The existence and proper functioning of a procedural framework is a precondition for the effective implementation of EU law (Nehl 1999, 2; Kanska 2004, 10). The right to a reasoned decision may, for instance, be regarded as a tool for enforcing a Union right such as the right of free movement of workers (Case 222/86 Unectef v. Georges Haylens and others [1987] ECR 04097, para 15). It may in other words be a 'gateway' to this fundamental right of EU law (Kanska 2004, 301; Craig 1999, 34).

Article 41 of the EU Charter of Fundamental Rights lays down good administration as a fundamental right by declaring the right of every person to have his or her affairs handled in a certain way by the institutions and bodies of the Union. This is a declaration of individuals' subjective right to good administration. Accordingly good administration is not limited to being a factor in the realization of other rights. It is not a gateway to other rights, but an end in itself (Kanska 2004, 301; Harlow and Rawlings 1997, 497). ${ }^{1}$

Being phrased as a subjective individual right and a citizen's right, good administration not only requires administrators to act in accordance with legal requirements, but also provides citizens with protection in the form of an enforceable right which they can rely on in their relations with administrative bodies (Wakefield, 2007, 58-59). While the Charter's provisions are applicable to the institutions and bodies of the Union, and to the Member States when they are implementing Union law (cf. Article 51 of the Charter), Article 41 is applicable to the institutions and bodies of the European Union. By omitting to provide for its applicability to Member States when implementing Union law, Article 41 seems to define the scope of the right to good administration as being narrower than that generally laid down by the Charter.

This paper discusses this particularity of the right to good administration. It questions the reasons for the demarcation of Article 41 and examines its conformity to the status of good administration as a subjective, fundamental Treaty right and whether the limited scope of Article 41 in fact affects the applicability of the right to good administration to situations in which persons deal with Member States. The recognition by the European Court of Justice of the right to good administration as a general principle of EU law plays an important role in this context. The codification of the general principle in the Charter raises questions as regards the interplay between unwritten and written fundamental rights within the Union's legal order (de Vries 2012, 13, 22-23). This is an important question, as its answer may determine the outcome as regards the applicability of the right to good administration in situations in which Member States implement EU law. 
As an introduction, Sections 1 and 2 will provide some basic information on the status of the Charter, its basis and the content of the concept 'good administration' as analyzed by legal scholars. Section 3 discusses the scope of the right to good administration. It focuses on the implications of the demarcation of Article 41 of the Charter and raises the questions whether this provision actually limits the applicability of the right to good administration to situations in which persons deal with EU institutions, whether it precludes the application of the general principle of good administration, established by the European Court of Justice, in Member States - and finally what effect, if any, the formal recognition of the principle of good administration has on the implementation of EU law in Member States. The Section then examines whether and how the European Court of Justice has addressed the matter with respect to these questions. Section 4 provides concluding remarks.

\section{The EU Charter of Fundamental Rights - Basis, Development and Present Status}

The present status of the Charter of Fundamental Rights as a legally binding document, acquired by the entry into force of the Treaty of Lisbon in December $2009,{ }^{2}$ is the latest step in the development of the position of fundamental rights within the European Union. The European Court of Justice provided the first step by its use of general principles of $\mathrm{EU} \mathrm{law}^{3}$ and the second step was taken by the adoption of the Charter of Fundamental Rights (Groussot 2006, 105), where general principles were codified in a written document. ${ }^{4}$ The Preamble to the Charter ${ }^{5}$ confirms the important role of the Court in this connection as it refers to the case-law of the Court as a basis for the rights, freedoms and principles set out in the Charter, along with the constitutional traditions and obligations common to the Member States on both the international and European level and case law of the European Court of Human Rights.

Although not legally binding until 2009, the Charter was considered to have an 'influential and significant role in the building of a European corpus of law protecting human rights.' (Dutlheil de la Rochére 2007, 157). Scholarly writings generally recognized the Charter's importance, stressed its influential effect and hinted at its future capabilities, leaving it for the future to reveal its actual effect (Dutlheil de la Rochére 2007, 159; Nehl 1999, 1). For a while the Charter was destined to be included in the EU Constitutional Treaty. When that project did not come into existence, the question of the Charter's legal destiny was raised again (Dutlheil de la Rochére 2007, 159) and answered by the Treaty of Lisbon. Through the ratification of the Treaty, the status of the Charter changed from a document of codified principles to a legally binding document. Its legal value also became the same as that of the Treaty ( $c f$. Article 6(1) TEU ${ }^{6}$ ). Although it is not incorporated in the Treaty, this reference makes the Charter a part of the EU Treaty and gives it a status as such (Groussot and Pech 2010, 2). This is an important fact to keep in mind in the discussion of the subject matter of this paper, the principle of good administration and its applicability to Member States when implementing EU law. 


\section{The Right to Good Administration}

\subsection{Article 41 of the Charter of Fundamental Rights}

The right to good administration is among the citizens' rights listed in Chapter V of the EU Charter of Fundamental Rights. Article 41(1) states the right of every person to have his or her affairs handled impartially, fairly and within a reasonable time by the institutions and bodies of the Union. According to the provisions of the second paragraph, 41(2), this right includes the right of every person to be heard before any individual measure which would affect him or her adversely is taken. It also includes the right of every person to have access to his or her file, while respecting the legitimate interests of confidentiality and of professional and business secrecy. The right to good administration furthermore includes the obligation of administrative bodies to give reasons for their decisions. Article 41 also states the right of every person to have the Union make good any damage caused by its institutions or by its servants in the performance of their duties, in accordance with the general principles common to the laws of the Member States (41(3)) and allows every person to write to the institutions of the Union in one of the languages of the Treaties and to have an answer in the same language.

\subsection{The Basis of Article $\mathbf{4 1}$ of the Charter}

The Preamble to the Charter makes reference to various sources, including national and constitutional traditions, international law, the case-law of the European Court of Justice and the European Court of Human Rights. While it is true that the subject matter of Article 41 is well established administrative principle in national legislations committed to the rule of law, it has generally not been constitutionalized in national law (Groussot and Pech 2010, 5). Being proclaimed as a fundamental right is special in this respect, ‘perhaps even revolutionary' (Wakefield 2007, 3). The right to good administration is furthermore not covered by the ECHR or other international obligations referred to in the Preamble. The right to good administration differs from other rights set forth in the Charter in this respect.

The case law of the European Court of Justice, on the other hand, is an important source for the position granted by the Charter to the right to good administration. The influence of the Court as regards general principles of EU law has been widely acknowledged. This also applies to the principle of good administration. The presentation of good administration in the form of a right derives from a general principle of good administration, ${ }^{7}$ developed in the case-law of the Court ${ }^{8}$ on the basis of the rule of law. ${ }^{9}$

As pointed out in 2.3 below, Article 41 is an umbrella provision comprising various administrative rules. It must, however, be pointed out that the various rights included may have developed separately in the Court's jurisprudence. ${ }^{10}$ This will not be accounted for in this paper. 


\section{STJÓRNMÁL \& \\ STJÓRNSÝSLA}

\subsection{What is Good Administration?}

The way the right to good administration is set out in Article 41 of the EU Charter of Fundamental Rights does not give a full picture of its content. In fact it has been considered to be a 'compilation, albeit incomplete, of separate rights developed by the Court and, in addition, a formulation of a general right to good administration' (Kanska 2004, 305). This requires some explanation. Although it is not the aim of this paper to analyze or give an account of the different components of good administration, a few points will be made in this connection.

Firstly, the rights enumerated in Article 41 of the Charter may include or incorporate, other administrative principles not explicitly worded in its paragraphs. The first paragraph defines good administration as the right to have affairs handled impartially, fairly and within reasonable time. It does not mention the principle of care (Groussot $2006,250)$ or due diligence, (Reichel 2008, 246) which includes the duty to reply to requests, duty to act in due time, to collect sufficient information and examine a request (Groussot 2006, 253). These have however been considered to fall under the wider principle of good administration and to be included in the scope of Article 41(1) (Groussot 2006, 257, Tridimas 2006, 412)

Secondly, Article 41 is an umbrella provision (Kanska 2004, 312). As the sub-rights stated in Article 41(2) are enumerated in a non-exhaustive manner, (Dutlheil de la Rochére 2007, 169; Kanska 2004, 322, of. the wording 'including'), the scope of the right to good administration is not limited to the rights directly enumerated. It is therefore capable of comprising rights other than those specifically enumerated in Article 41(2), i.e. other than the right to be heard, have access to one's file and the obligation of the administration to give reasons for its decision. This will be the approach in this paper.

In this connection it is noteworthy that principles touching upon important substantive administrative law, for instance the principles of proportionality and legal certainty, are not mentioned in Article 41 (Kanska 2004, 322). This leads to my third point, which is a reminder that Article 41 comprises both procedural and substantive requirements that provide individuals with tools to invoke in their dealings with public authorities. The same applies to their dealings with EU institutions handling matters concerning them (Reichel 2008, 244).

The final point does not concern the content of the principle of good administration, but rather its objective. The aim of EU administrative (and national) law in general is in brief, administrative efficiency and the protection of the citizens vis-à-vis actions of the state. Declaration of good administration as a fundamental right clearly relates to the latter. ${ }^{11}$ This focus has been criticized for offering a one-sided vision of the function of administrative law and has been considered misplaced in the Union context (Kanska 2004, 324). The one-sided vision may be true. But can it be otherwise in a Human Rights document? As a Human Rights document, the Charter's objective is to strengthen the protection of fundamental rights. ${ }^{12}$ It coincides with the aim of administrative rules to protect citizens vis-à-vis the State. What is at stake here is not the function of administrative law, but the establishment of good administration as a fundamental right. 


\subsection{The Innovative Features of Article $\mathbf{4 1}$ of the Charter of Fundamental Rights}

Apart from providing, to some degree, an authoritative definition of the right to good administration, Article 41 of the Charter is not really an innovation. Neither the aim nor the substance of the principle of good administration is new to administrative law. The innovative value of Article 41 consists, amongst other things, in its declaration of good administration as a subjective right (Dutlheil de la Rochére 2007, 168; Kanska 2004, 300, 302; Wakefield 2007, 3). As a subjective right, good administration can be relied upon by the citizens in their relations with public authorities in the same way as other subjective rights stated in the Charter. Just as they can refer to the right to freedom of thought, conscience and religion ( $c f$. Article 10 of the Charter), they can claim the right to be given reasons for an administrative decision. In both instances, citizens are provided with a tool to enforce their claims vis-à-vis administrative bodies (Kanska 2004, 300).

Being of procedural character, the tools specifically formulated in Article 41 do not define rights and duties or form a basis of a claim for the issuance of a particular decision or the grant of certain benefits (Kanska 2004, 301). Their substance is, however, based on norms and values 'commonly recognized by any modern democratic system of governance committed to the 'rule of law' (Nehl 1999, 17). As norms and values of procedural law (Kanska, 2004, 301), administrative rules are the substantive rules governing the communication between administrative bodies and individuals. They require the former to act in a certain manner and provide protection to the latter in their relations, not only in their realization of other substantive rights but as a substantive right in itself. The independent meaning of good administration implied by Article 41 is interesting, especially given the previous debate among scholars on the matter. ${ }^{13}$

The innovation in Article 41 of the Charter also appears in the documentation of good administration as a fundamental right of constitutional status (Kanska 2004, 302). This is new not only at the EU level, but also at the international and national level (Kanska 2004, 297). The acquisition of this status is interesting in the light of the fact that the status of good administration as a general principle in EU administrative law had been questioned. ${ }^{14}$ There is considerable difference between a denial of the existence of a right (Nehl 1999, 36) or the status of general rules requiring a certain standard of proper procedures (Nehl 1999, 16) on the one hand, and a declaration of a fundamental right on the other. The status acquired by the Charter of fundamental rights seems to have proved earlier predictions (Nehl 1999, 1) as regards its further evolution in this respect to be correct.

\section{The Scope of the Right to Good Administration}

As a written, legally binding subjective fundamental right, the right to good administration has become a 'cardinal element of the Union's body of 'primary', that is 'constitutional' rules' (Groussot and Pech 2010, 2). It imposes a duty on administrative bodies and lays down a source upon which the citizens may rely in their dealings with them. A reservation as regards impact in this respect may, however, be called for here as the scope, as defined by Article 41, may affect the actual implications of this status. 


\section{STJÓRNMÁL \& STJÓRNSÝSLA}

\subsection{Article 51 of the EU Charter - Implementation of Union Law}

Article 51 defines the general scope of the EU Charter of Fundamental Rights. The Charter's provisions are applicable to the institutions and bodies of the Union and to the Member States when they are implementing Union law. This means that national authorities must respect such rights when they act within the scope or field of Union law (Groussot, Pech and Pétursson 2012, 135). ${ }^{15}$ When, on the other hand, they act on the basis of national law, outside the scope or field of Union law, they are not under any such obligation (Groussot, Pech and Pétursson 2012, 147). ${ }^{16}$

What constitutes an implementation of Union law in the sense of Article 51(1) of the Charter as regards the relationship between national and EU law has been a matter of discussion among legal scholars. Legal analyses in the Charter's early years, before its entry into force, often referred to uncertainty (Eeckhout 2002, 969), disagreements (Fenger 2004, 105-113) and different opinions (Craig 2006, 502) on how to interpret the words 'implementation of Union law'. Even in 2010, when the Charter had become binding for Member States, there is reference to the different views of academic commentators (see, for instance, Craig 2010, 211) and a hope expressed for a remedy of deficiencies of the Charter on this point (Groussot and Pech 2010, 6). In 2012 there were still comments on difficulties as regards the interpretation of this term (de Vries 2012, 22). ${ }^{17}$ Based on the different views on the interpretation of Article 51, the European Court of Justice was criticized either for expanding ${ }^{18}$ the scope of Article 51 or for not doing so. ${ }^{19}$ The call for a remedy may have been answered by the Grand Chamber's decision of 26 February 2013 in the Akerberg case (C-617/10 Aklageren v. Hans Akerberg Fransson, Judgement of 26 February 2013) which will be discussed below. Whether it will also be subject to criticism remains to be seen.

As examples of the different views, an expansion of the Charter's applicability has on the one hand been considered preferable in normative terms (Craig 2010,212) and been believed to reinforce the Charter's intention 'to capture the various senses in which Member States could be said to be acting in the scope of Union law' (Craig 2010, 212). Furthermore it has been pointed out that the wording of Article 51 does not require a narrow interpretation (Craig 2006, 502) and that the explanatory memorandum strongly supports a broad interpretation (Craig 2010,212). On the other hand, a caution has also been sounded against a broad interpretation: though important, fundamental rights cannot justify expansion of Union principles at the cost of national autonomy (Fenger 2004, 113).

The variable wording in the Explanatory Notes at different stages has not been helpful in this respect. The wording 'act in the context' and 'within the scope' of Union law may suggest a broader scope than the word 'implementation' (Eeckhout 2002, 955). The reference to the existing corpus of the Court's jurisprudence may, however, be of importance (Craig 2010, 211). The relevance of existing case-law at the time was not expressly overruled by the Treaty of Lisbon. On the contrary, it stresses that the Charter's provisions are based on existing law (Craig 2010, 212).

While things may be said about the wording and the drafting deficiencies of Article 
51 of the Charter of Fundamental Rights and its interpretation, its alleged obscurity does not seem to have interfered with the applicability of the Charter to national authorities in the application of EU law involving protection of fundamental rights (Groussot and Pech, 6). ${ }^{20}$ There also seems to be room for an independent obligation to respect fundamental rights within the implementation of EU law (de Vries 2012, 12).

The latest step in the evolution of the interpretation of this provision as regards the relationship between national and EU law appears in the Court's decision in the Akerberg case mentioned above. Firstly, the Court supports a broad interpretation of Article 51(1) which, in the Court's view, 'confirms the Court's case law relating to the extent to which actions of the Member States must comply with the requirements flowing from the fundamental rights guaranteed in the legal order of the European Union.' (C-617/10, Akerberg, para 18). In this the Court denies, with reference to the Explanatory Note on Article 51, that it leads to a restriction on the application of its previous case-law on fundamental rights. Then the Court declared that fundamental rights guaranteed in the legal order of the EU are applicable in all situations governed by EU law. Thus, if national legislation falls within the scope of EU law, that legislation must be compatible with the fundamental rights guaranteed (C-617/10, Akerberg, para 19), including those guaranteed in the Charter of Fundamental Rights (C-617/10, Akerberg, para 21). ${ }^{21}$

The remaining, and the main, task in this paper is to examine the scope of the right to good administration as defined in Article 41. Given the conclusion in Akerberg that the provisions of the EU Charter of Fundamental Rights are applicable to Member States when national measures fall within the scope of EU law, one would assume that this is also true of the right to good administration as stated in the same Charter. The wording of Article 41, however, suggests otherwise.

\subsection{The Demarcation of Article 41- Is it in Fact a Limitation?}

\subsubsection{No mention of Member States}

Like the other rights stated in the Charter, the right to good administration is a fundamental right. A particularity of the right to good administration appears in the definition of the scope of this specific right in Article 41. As already explained, this provision states the right of every person to have his or her affairs handled in a certain way by the institutions and bodies of the Union. It does not mention Member States. Its scope therefore seems to be defined as being narrower than that of the Charter as a whole ( $c f$. Article 51 of the Charter).

The title of this Section may indicate a doubt on my part as regards the real implication of this limitation. The wording of Article 41 of the Charter of Fundamental Rights certainly argues against entertaining such doubts, as it quite clearly states the rights of individuals regarding how their affairs are treated by the institutions and bodies of the Union, and contains no mention of obligations on the Member States. The wording is clear, so what grounds are there for thinking that it means something else?

My hesitance is rooted in the view that good administration is a general principle of 
EU law and a fundamental Charter right. The limited scope of Article 41 does not seem to be in conformity with this status.

The reasons for the different scope applying to the right to good administration is not addressed in the Charter, either in its Preamble or in the Explanatory Notes. It might possibly be explained by the "doctrine of procedural autonomy" discussed in 3.2.2 below. For instance, it has been suggested that the limited scope of Article 41 was intended to reassure Member States 'that they will not have to take into account the principle of good administration in purely national administrative procedures, including those involving application of Community law.' (Dutlheil de la Rochére 2007, 170). This suggests that Article 41 not only excludes its applicability to Member States as regards their implementation of purely national law, but as regards their implementation of Union law as well. Whereas Article 51 of the Charter makes a distinction between the implementation of EU law and national law, Article 41 seems to exclude both from its scope.

\subsubsection{The Doctrine of Procedural Autonomy}

The doctrine of direct effect and supremacy requires states to implement and apply law in accordance with EU law. The doctrine of procedural autonomy allows Member States to decide by whom and how the implementation takes place. Accordingly, Member States may lay down the procedural rules governing their actions (Reichel 2008, 256). The scope of the right to good administration as defined in Article 41 seems to coincide with this, limiting the applicability of this right to the bodies and institutions of the Union and thereby leaving the procedures to the Member States.

However, the doctrine of procedural autonomy is not without limitations. Procedural autonomy may be affected when Member States' actions fall within the sphere of Union law in the meaning of Article 51, as discussed above. In such cases, substantive Union law may require Member States to apply their procedural rules differently in order for the law to be effective or ensure the appropriate level of protection of rights and guarantees established by general principles of Union law (Reichel 2008, 258). It then functions 'as a vehicle to strengthen private parties' possibilities to bring about an effective application of their Community rights before national authorities' (Reichel 2008, 265). This fits in with the 'gateway theory', which regards procedural rules as the means by which EU rights and principles may be properly protected. As a fundamental citizens' right, good administration must set the standard required. Thus, if national procedural rules do not ensure the correct level of protection, the doctrine of procedural autonomy is not applicable.

There are three main limitations to the doctrine of procedural autonomy. Firstly, it does not apply to the implementation of a Union rule with direct effect. Therefore, if the rule at issue is Treaty-based (Reichel 2008, 257), its implementation is not subject to the doctrine of procedural autonomy. Secondly, the doctrine of procedural autonomy does not exclude the application of procedural rules in secondary EU law (Reichel 
2008, 267-8). Due to Union consistency and effectiveness requirements, Member States must comply with such rules. They are not free to lay down their own rules. Procedural rules in EU directives therefore take precedence over national rules. Thirdly, procedural autonomy does not apply to the application of general principles of EU law. Union rules which reflect general principles function as minimum standards to be respected by Member States (Reichel 2008, 258, 261). They do not leave room for Member States to decide their own procedural rules governing such principles. So if national law does not fulfil minimum standards, the doctrine of procedural autonomy is not applicable.

If the above exceptions apply, the doctrine of direct effect and supremacy requires Member States to ensure the application of EU legislation and principles. Rules which are used to give effect to EU legislation and principles must be applied accordingly. Member States do not have procedural autonomy as regards how the actions at issue are governed if their rules do not ensure the fulfilment of EU law and principles.

The question at hand is how the right to good administration stated in Article 41 of the Charter of Fundamental Rights fits into the doctrine of procedural autonomy. If this doctrine applies, Member States need only follow their own administrative rules. If, on the other hand, its limitations apply, one would assume that Member States have to take the right to good administration into account.

The right to good administration fits easily into the second of the three limitations identified above. If EU directives include procedural rules, ${ }^{22}$ the Member States must follow their procedural instructions. They can provide neither more nor less protection than is intended by the legislator, as interpreted by the Court (Reichel 2008, 267).

The exception applying to a Treaty-based rule ( $c f$. the first of the three limitations identified above) also seems to be present. The duty imposed by Article 253 TEU on administrative bodies to give reasoned decisions is a clear example of such a rule. As discussed in Section 1 above, Article 6(1) TEU provides that the rights, freedoms and principles of the Charter of Fundamental Rights 'shall have the same legal value as the 'Treaty.' The status of the right to good administration, with all its components, therefore does not differ from that of the Treaty-based right to reasoned decisions in this respect, and therefore it is not subject to the doctrine of procedural autonomy.

Application of the general principles of EU law ( $c f$. the third of the limitations identified above) also results in deviation from the doctrine of procedural autonomy. As has already been mentioned, the right to good administration reflects a general principle of EU law. It is submitted that as a general principle of EU law, its application falls within the limitations of the doctrine of procedural autonomy. Therefore the general principle of good administration is not subject to the doctrine of procedural autonomy.

Although Article 41 of the Charter seems, on the face of it, to be consistent with the doctrine of procedural autonomy it does not take the doctrine's limitations into account. All three limitations seem to apply. Accordingly, this doctrine hardly forms the basis for the limited scope of the right to good administration as it is defined in Article 41. The doctrine of procedural autonomy therefore does not support a general assumption that Member States' administrative obligations are restricted to their administrative law and 
that they do not have to take the principle of good administration into account when acting within the scope of Union law. Accordingly, the doctrine of procedural autonomy does not require a distinction to be made between the scope of this right and the other rights in the Charter.

The doctrine of procedural autonomy nevertheless seems to have affected the drafting of the Charter of Fundamental Rights. It has also been a relevant factor in the rulings of the Court (Reichel 2008, 266, 271). As mentioned in 3.2.1 above, the narrow definition of the scope of Article 41 seems inconsistent with its declaration of good administration as a fundamental right. Before exploring the Court's rulings I want to address this and other factors that contribute to the criticism of Article 41 of the Charter.

\subsubsection{Significance of the Status of Good Administration as a Fundamental Right, a Charter Right and a General Principle of Union Law}

Contrary to Article 51 of the Charter of Fundamental Rights, Article 41 is silent about its applicability to Member States. Were it not for this silence, or were it also silent about the Union's administration, there would not be reason to doubt the scope of the right to good administration. It would be determined by Article 51 and the right to good administration would be applicable to Member States when implementing Union law in the same way as other rights stated in the Charter are applicable to Member States. Furthermore, it is submitted that without its codification in the Charter of Fundamental Rights, the general principle of good administration, which is not limited to EU administration $^{23}$, would determine the scope of application of this right.

As has already been mentioned, the inclusion of the right to good administration in the Charter of Fundamental Rights constitutes a formal recognition of this right as a fundamental right. As such, it is an important 'element of the Union's body of 'primary', that is, 'constitutional' rules' (Groussot and Pech 2010, 2). In this light, the scope of Article 41 of the Charter seems strange, in particular in view of its purpose to provide guarantees for individuals during administrative procedures. Although Article 41 may serve this purpose as regards institutions and bodies of the Union, the question remains whether this objective may be fully achieved by excluding Member States from its scope and how this fits in with the proclamation of good administration as a fundamental right.

The limitation of Article 41 has also been found to be strange in the light of the tendency otherwise shown by the Court towards imposing common standards on the Member States when implementing EU law (Kanska 2004, 309). It has been criticized for not providing an administrative model for national systems to follow. As Member States have different national rules, the Charter could have served as a ground for a common administrative order within the EU and contributed to the coordination of the implementation of EU law in the Member States (Kanska 2004, 310).

As has already been discussed, the right to good administration is based on a general principle of EU law. The Explanatory Notes on Article 41 do not imply an intention to 
overrule the Court's jurisprudence in this connection. On the contrary, they make special reference to the case-law of the Court as a basis for the Charter's rules. The scope of good administration defined in Article 41 therefore also raises questions as regards its conformity to the general principle of good administration.

It appears to be the prevailing opinion in the literature that the Charter should not detract from the case-law of the Court (de Vries 2012, 22). Therefore its scope should coincide with that of the general principles of EU law (de Vries 2012, 22). If this is applied to the right to good administration, Article 41 of the Charter should not relieve the Member States of the duty to apply good administration as a general principle. In this sense, the demarcation of Article 41 also seems impractical (Dutlheil de la Rochére 2007, 170).

The above discussion questions the limited scope of the right to good administration in the light of its proclaimed fundamentality and its objective. It also points to its failure to coordinate the implementation of EU law in the Member States. It furthermore suggests that, if interpreted literally, the scope of Article 41 not only deviates from the general scope of Article 51 but from a general principle of EU law as well. Therefore it also seems to affect the significance of Article 6(1) and (3) TEU regarding the Charter and general principles as Union norms ensuring the protection of fundamental rights in the EU.

These points give rise to questions regarding the real implications of Article 41 as regards the scope of good administration. Included are questions such as: (1) whether Article 41 of the Charter in fact limits the applicability of the right to good administration to situations in which persons have dealings with EU institutions, (2) whether the wording of Article 41 precludes the application of the general principle of good administration in Member States and (3) what, if any, effect the formal recognition of good administration has on the implementation of EU law in Member States? The following Section will focus on whether and how the European Court of Justice has addressed such questions.

\subsubsection{The European Court of Justice}

The case-law study below will examine the position of the European Court of Justice as regards the scope of the right to good administration as defined in Article 41 of the Charter of Fundamental Rights. The cases are chosen with respect to their references to the right to good administration and with a view to the specific questions above. As the Charter is considered to have had influence before it became legally binding, and for the purposes of examining the effect of its taking effect, the discussion will include both pre- and post-Lisbon cases.

As has already been discussed, Member States must comply with Treaty rules in their implementation of Union law. This is confirmed, for example, in joined cases C-147/06 and C-148/06, (SECAP SpA and Santorso Soc. Coop. Arl v. Comune di Torino [2008] ECR I-03565) ${ }^{24}$ concerning procedures for the award of public work contracts. The case included the question whether a tenderer suspected of submitting an abnormally low 


\section{STJÓRNMÁL \& \\ STJÓRNSÝSLA}

tender had a right to state his point of view and supply relevant explanations before being excluded from the award of a contract. In this case, Advocate General Colomer addressed the question whether the right to good administration imposed obligations on Member States on these grounds (i.e. as a Treaty rule). ${ }^{25}$ The Advocate General's Opinion, delivered on 27 November 2007, concluded that the right to be heard before dismissal did not constitute a fundamental principle of the Treaty. Therefore an automatic exclusion of abnormally low tenders did not run counter to any fundamental principle of the Treaty (Joined cases C-147/06 and C-148/06, Opinion of AG Colomer, para 31). The Advocate General did not leave the matter there, however, but pointed out that all the Member States provided for the right to be heard in their legal systems and also that it was a part of the right to good administration enshrined in Article 41 of the Charter of Fundamental Rights (Opinion of AG Colomer, para 50).

It must be acknowledged that the principle of good administration was only one argument in the Advocate General's conclusion. However, its status as a general principle in the EU Member States' legal systems and that fact that it is declared as a fundamental right in the Charter clearly contributed to the conclusion in this case, i.e. that national legislation may not oblige national authorities automatically to exclude abnormally low tenders without further notice (Opinion of AG Colomer, para 57). The limited scope of Article 41 is not specifically addressed in this connection. Whether this implies that its limitation is irrelevant in the Advocate General's opinion will not be examined here.

The demarcation of Article 41 of the Charter is addressed by Advocate General Kokott in Case C-75/08 Mellor (C-75/08 Christopher Mellor v. Secretary of State for Communities and Local Government [2009] ECR I-03799), concerning the question whether a national authority must state reasons for the decision not to carry out an environmental impact assessment. ${ }^{26}$ In the opinion, delivered on 22 January 2009, it is pointed out that although the Charter does not have binding legal effect, it does 'shed light on the fundamental rights which must be taken into account in interpreting Community law' (C-75/08 Mellor, Opinion of GA Kokott, para 24). As a consequence of the limitation in Article 41, however, this provision 'cannot simply be transposed without more ado to bodies of the Member States' and this is the situation 'even when they are implementing Community law.' (Opinion of GA Kokott, para 25).

The wording 'without more ado' is interesting. It indicates that in spite of the limitation in Article 41, Member States may not be altogether free when enacting procedural rules with a view to the application of Union law (Opinion of GA Kokott, para 27). Although good administration is not imposed as an obligation on Member States on grounds of Article 41, the right of their citizens to good administration is not dismissed. Instead its context is viewed and the conclusion reached, with reference to the Court's case law, is that not only does Article 41 'contain rules of good administration by the institutions, but documents a general principle of law, which authorities of the Member States too must observe when applying Community law.' Therefore, Member States were obliged to state reasons for the decision taken in the case (Opinion of GA Kokott, paras 33 and 34). 
It must be noted that the Court did not address the scope of Article 41 in its Judgement of 30 April 2009 in this case. Neither did it do so in its decision of 25 March 2010 in Case C-392/08 (European Commission v. Kingdom of Spain [2010] ECR I-02537) concerning time-limit, as regards the fulfilment of an obligation to draw up external emergency plans in accordance with Directive 96/82/EC on the control of major accident hazards involving dangerous substances. On the other hand, Advocate General Kokott did address this matter in his opinion of 10 December 2009. Interestingly, in this case the former reservations as regards the applicability of the obligation to provide good administration to Member States are not mentioned:

As article 41(1) of the Charter of Fundamental Rights of the European Union expressly provides, public authorities must, in addition, fulfil their obligations within a given time-limit in compliance with the principle of good administration, to which the Member States must also have regard when applying Community law. Thus the Member States may not unduly delay the drawing up of the external emergency plans. (para 16).

In this opinion, which was delivered a few days after the Charter's entry into force, Advocate General Kokott neither mentions its recently acquired status as a binding legal document nor its limitations as regards its scope. Whether the omission of the reservation in Mellor is due to the Charter's having become legally binding and a part of the Treaty at the time of the opinion in this case is not clear.

The limitation in Article 41 is, on the other hand, addressed in the Court's judgement of 21 December 2011 in Case C-482/10 Cicala (Teresa Cicala v. Regione Siciliana [2011] Judgement 21 December 2011), where the Court states that 'according to its wording Article 41 of the Charter is addressed not to the Member States but solely to the EU institutions and bodies.' (Judgement 21 December 201, para 28). Case-277/11 (M.Mv. Minister of Justice, Equality and Law Reform [2012] ECR I 00000. Judgement 22 November 2012), concerning the Common European Asylum System, includes a question regarding the applicability of the right to be heard to citizens of Member States. In his opinion of 26 April 2012, Advocate General Bot claims that this right must, as a general principle of EU law, be 'applicable in any procedure which may culminate in a decision of an administrative or judicial nature adversely affecting a person's interest.' This requirement not only applies to 'the EU institutions by virtue of Article 41(2)(a) but also, because it constitutes a general principle of EU law, it applies to the authorities of the Member States 'when they adopt decisions falling within the scope of EU law, even when the applicable legislation does not expressly provide for such a procedural requirement.' (C-277/11, Opinion of AG Bot, paras 31 and 32). As a consequence, a national authority is 'obliged to ensure, when it adopts a decision falling within the scope of EU law, observance of the right of the person concerned to good administration, which constitutes a general principle of EU law.' (Opinion of AG Bot, paras 31 and 32).

The Court referred in this same case to the right to be heard as a fundamental principle of EU law, now affirmed by the Charter, particularly Article 41(2) which, due to its wording is of 'general application' (C-277/11, paras 82 and 84). The Court furthermore states that 'according to its case-law, the Member States must not only interpret their 
national law in a manner consistent with EU law but also make sure they do not rely on an interpretation which would be in conflict with the fundamental rights protected by the EU legal order or with the other general principles of EU law' (C-277/11, para 93), including the right to be heard.

Both the Court and Advocate General Bot maintain the applicability of the right to be heard to citizens of Member States based on a general principle of EU law. The Court also refers to the right to good administration in Article 41 as a fundamental right. While Advocate General Bot explicitly rejects applicability based on Article 41, the Court does not seem to pay attention to its limitations. However, the comment on its 'general application' is not quite clear in this respect.

The above coverage of the case-law indicates that Opinions of Advocates General are more likely than the Court to address the matter of good administration, its basis and its scope. This is consistent with earlier comments made by Advocate General Colomer in Case 303/2005 (Advocaten voor de Wereld VZW v Leden van de Ministerraad [2007] ECR I-3633), regarding the Advocates General being willing to refer to the Charter and by interpretation transcend its programmatic and declarative nature, whereas the Court rarely cites the Charter 'not even to refute the views put forward by the Advocates General.' (Case 303/2005, Opinion of AG Colomer, para 78). Now, a few years later, the Court seems to have broken its silence in this respect.

The above discussion also provides some answers to the questions asked above regarding the applicability of the right of persons to good administration in their dealings with Member States. It shows that, prior to the Treaty of Lisbon, the Court denied the applicability the obligation on Member States to provide good administration, on the grounds that it was not a Treaty rule. The Charter's acquisition of a Treaty status with the entry into force of the Treaty of Lisbon does not, with the exception of the opinion of Advocate General Kokott in C-392/08, change the non-applicability of the right to good administration in situations in which persons deal with Member States. This position is explained by how its scope is defined in Article 41. The question whether Article 41 in fact limits the applicability of the obligation to provide good administration on the institutions and bodies of the EU must therefore be answered in the affirmative. Its wording excludes direct applicability to Member States.

The case-law also demonstrates the applicability of good administration to Member States as a general principle of EU law. As a general principle, the right to good administration requires certain administrative standards of the Member States in their implementation of EU law. ${ }^{27}$ The Member States must therefore respect the right to good administration, not because of Article 41, but in spite of its wording. The second question must therefore be answered in the negative. The wording of Article 41 does not preclude the applicability of the general principle of good administration to Member States. The Charter provision does not displace it.

As regards the third question, references to Article 41 in the case-law also seem to suggest that its declaration of good administration as a fundamental right is, in spite of its scope, of some, perhaps incentive, value. Its formal recognition therefore seems to 
affect legal reasoning and contribute to some extent to the protection of administrative rules in the implementation of EU law.

\section{Concluding Remarks}

With reference to Section 3.2.2, the limited scope as defined by Article 41 of the Charter of Fundamental Rights cannot be explained by the doctrine of procedural autonomy. It is submitted that because of the Treaty status of the EU Charter of Fundamental Rights and the fact that good administration is a general principle of EU law, the right to good administration is subject to the exceptions to this doctrine. However, this right was decisively limited by the wording of Article 41. The case-law discussed above confirms this. The demarcation of Article 41 actually limits the protection it confers to instances of dealings with EU institutions.

The decision to define the scope of Article 41 in this way was made in spite of good administration's being a general principle in EU law which does not exclude Member States. The scope of the right to good administration therefore was not only defined as being narrower than the scope of the Charter in general, but narrower than that of the general principle as well. This seems strange considering the role general principles played in the Charter's foundation. Limiting the scope of a general principle established by the case-law of the European Court of Justice, in a document which was meant to codify the same principle, seems somewhat odd. The decision to restrict the applicability of a right parallel to its declaration as a fundamental right also raises questions.

As the case-law reveals, the limitation in Article 41 does not affect the applicability of the general principle of good administration to Member States. Given that the general principle of good administration prevails over Article 41 when it excludes the application of the principle of good administration to Member States, the decision to exclude Member States from its scope also seems highly impractical.

However, this limitation does not seem to reduce the weight of the fundamentality of this right. The Charter's status as a legally binding document with a Treaty basis gives the rules stated in its provisions constitutional status (Groussot and Pech 2010,2) and indicates that they were not intended to be 'merely aspirational' (Wakefield 2007, 92). Article 41 of the Charter clearly states the fundamentality of the right to good administration. Its status as an independent right with the aim of providing guarantees for individuals during administrative procedures also suggests that it was meant to have a substantive meaning. This may also be inferred from case-law concerning the application of good administration in the implementation of EU law. References to Article 41 indicate that its status as a fundamental Charter right has some weight in legal argumentation. The formal recognition involved in codification as fundamental right in the legal order of the Union therefore seems to have a certain impact on the application of the principle of good administration in the implementation of EU law. Through the Charter it has gained visibility and thereby the legal certainty of those who are subject to its protection is enhanced.

Codification may also have value for the further evolution of the right to good ad- 
ministration. It has been pointed out that the right to good administration may in the future be enhanced through its codification in secondary legislation and the interpretation of this principle as a legally enforceable guarantee for the individual (Reichel 2008, 271), which is its objective. Although these aspirations may not yet be achieved, the references made in the case-law to the subjective right stated in Article 41 may just be an important step in the development towards a common administrative order within the EU.

\section{Notes}

1 For a different view of the significance of good adiministration in this respect, see, for instance, Nehl (1999) 16, 20.

2 Treaty of Lisbon amending the Treaty on European Union and the Treaty establishing the European Community, signed at Lisbon, 13 December 2007 [2007] OJ C 306.

3 For a review of the origin, function and impact of general principles in EU law, see, for instance, Groussot 2006 and Tridimas 2000.

4 The Charter of the European Union of 7 December 2000, adapted at Strasbourg on 12 December 2007.

5 Consolidated Version of the Treaty of European Union OJ [2012] C 326/422-3

6 Article 6(1) TEU provides that the EU 'recognizes the rights, freedoms and principles set out in the Charter of Fundamental Rights of the European Union of 7 December 2000, as adapted at Strasbourg, on 12 December 2007, which shall have the same legal value as the Treaties.

7 This principle originated in the idea that citizens' rights and interests may be infringed by administrative action. As a reaction to the powers of administrative bodies, they are actively required to exercise their discretionary powers in such a way as to serve the lawful interests or specific rights of users, users being 'any third parties who are affected by the regulatory and productive activities of the administration', see Fortsakis 2005, 208.

8 It has even been suggested, although not approvingly, that 'good administration' within the Union in general is defined by 'what the Community Courts say it is' (Nehl. 1999, 18).

9 Explanations Relating to the Charter of Fundamental Rights [2007] OJ C303/28. On the rule of law, see also, inter alia, Wakefield 2007, 21, 54; Kanska 2004, 295 and Craig 2010, 408-9.

10 For a review of this development, see Groussot 2006, Chapter 4 on Administrative Principles of Fundamental Rights.

11 See Fortsakis 2005, 208-210, for a discussion on good administration as a factor in user protection.

12 OJ [2012] C 326/422.

13 See, for instance, Nehl 1999 37, who claims that the principle of good administration has 'no specific legal content and purpose of its own'. For later comments, see, for instance, Tridimas 2006, 412, who points out that, as a ground for judicial review this principle has mainly been used 'in a subsidiary and supportive role'.

14 See, for instance, Nehl 1999, 15-16 where he questions whether procedural 'good administration' is a principle of any significance in EC administrative law and a settled legal concept as in national legal order.

15 This approach was established in pre-Charter case-law: see, for instance, Fenger 2004, 104.

16 As for pre-Charter case-law, see, for instance, Fenger 2004, 105.

17 See also a review on the matter in Groussot, Pech, and Pétursson 2012, 137-148.

18 For example for including derogations from EU law to its scope, see further, Craig 2010, 210.

19 For instance 'whenever they act within the scope of EU law', see Craig 211, or 'in all cases and contexts where there is a material link with EU law', see Eeckhout 2002, 993.

20 This includes laws which enforce and interpret EU rules (Wachauf) or invoke derogation rules 
(ERT) relating to the fundamenal economic freedoms such as the free movement of goods. Interestingly, the above classification (to Wachauf and ERT type of cases) has been used as a basis for arguments in favour of an expansion of the Charter's scope to individuals (Wachauf à l'horizontale and ERT à l'horizontale), see Groussot, Pech, and Pétursson 2012, 156-167, referring to Kücükdeveci, Case C-555/07 [2010] ECR I-365, where the existence of a Directive on equal treatment in employment and occupation suffices to trigger the EU general principle of non-discrimination even if the Directive did not include a provision on the implementation of this right. This paper does not cover this aspect of the Charter. (Questions regarding the applicability of the Charter to private parties will be discussed to some length elsewhere.)

21 'Since the fundamental rights guaranteed by the Charter must therefore be complied with where national legislation falls within the scope of European Union law, situations cannot exist which are covered that way by European Union law without those fundamental rights being applicable. The applicability of European Union law entails applicability of the fundamental rights guaranteed by the Charter.'

22 The Service Directive and Directives on public procurement are examples of directives that focus on administrative rules in order to strengthen the position of the individual and harmonize their application.

23 Given that the scope of general principles of EU law is wider than the scope of the Charter in general (cf. de Vries 2012, 22).

24 Although a certain matter may fall out of the scope of secondary legislation (the value of a contract may for instance not reach the thresholds laid down in the directives on public procurement), it is still considered to be within the scope of the Treaty if it concerns fundamental Treaty rules (freedom of establishment, freedom to provide services) and fundamental principles (non-discrimination), see paras 20 og 35, and Case C-59/00 Ben Mousten Vestergaard v. Spöttrup Boligselskab [2001] ECR I-09505, para 20.

25 The Court in this case did not address this question on grounds of good administration. It did not refer to this right even though, at the time of its decision of 15 May 2008, the right to good administration had been proclaimed as a fundamental right in the Charter of Fundamental Rights for more than eight years and had been adopted a few months earlier, on 12 December 2007. Notably, the Charter was not legally binding at the time.

26 Directive $85 / 337$ /EEC states this obligation as regards a decision that a project is subject to an environmental impact assessment but is silent as regards a decision not to carry out such an assessment.

27 The general principle of good administration and its components may, however, provide a different level of protection when applied by Member States. Previous studies on this matter have shown that the principle of good adminstration does not place a clear obligation upon Member States to apply this principle in exactly the same way as is required at the European level, see for instance, Reichel 2008, 271-272.

\section{References}

Craig, P. (1999). Administrative Law. Hart publishing.

Craig, P. (2006). EU administrative law. Oxford University Press.

Craig, P. (2010). The Lisbon Treaty : law, politics, and treaty reform. Oxford University Press.

Dutlheil de la Rochére, J. (2007). 'The EU Charter of Fundamental Rights, Not Binding but Influential: the Example of Good Administration' in Anthony Arnull and others (eds), Continuity and change in EU law : essays in honour of Sir Francis Jacobs (p. 157-172). Oxford University Press.

Eeckhout, P. (2002). 'The EU Charter of Fundamental Rights and the Federal Question' Kluwer Law International 39, 945-994. 
Fenger, N. (2004). Forvaltning og fallesskab: om EU-rettens betydning for den almindelige forvaltningsret: konfrontation og frugtbar sameksistens. Jurist- og Økonomforbundets Forlag.

Fortsakis, T. (2005). 'Principles Governing Good Administration' European Public Law 11(2).

Harlow, C. and Rawlings (1997). Law and Administration. Butterworths.

Groussot, X. (2006). General Principles of Community Law. Europa Law Publishing.

Groussot X and Pech, L. (2010). 'Fundamental Rights Protection in the European Union post Lisbon Treaty' Foundation Robert Schuman/European Issue 173.

Groussot, X., Pech L., and Gunnar Thor Pétursson (2012). 'The Scope of Application of Fundamental Rights on Member States `Action: In Search of Certainty in EU Adjudication' in Ulla B. Neergaard and Ruth Nielsen (eds), European legal method: in a multi-level EU legal order (p. 135-163). Jurist - og Økonomforbundets Forlag.

Kanska, K. (2004). 'Towards Administrative Human Rights in the EU. Impact of the Charter of fundamental Rights.' European Law Journal 10, 296-326.

Mendes, J. (2009) 'Good Administration in EU Law and the European Code of Good Administrative Behaviour.' EUI Working Papers LAW. European University Institute.

Nehl, H.P. (1999). Principles of Administrative Procedure in EC Law. Hart publishing.

Reichel, J. (2008). 'Between Supremacy and Autonomy - Applying the Principle of Good Administration in the Member States' in Ulf Bernitz and others (eds), General principles of EC law in a process of development: reports from a conference in Stockholm, 23-24 March 2007, organised by the Swedish Network for European Legal Studies. Wolters Kluwer Law \& Business.

de Vries, S.A (2012). Balancing fundamental rights with the EU treaty freedoms: the European Court of Justice as 'tightrope' walker. Eleven International Publishing.

Tridimas, T. (2000). The General Principles of EC Law. Oxford University Press.

Tridimas, T. (2006). The General Principles EU Law. Oxford University Press.

Wakefield, J. (2007). The right to good administration. Kluwer Law International.

\section{Cases}

Case C-617/10 Aklageren v. Hans Akerberg Fransson (Judgement of 26 February 2013).

Case C-482/10 Teresa Cicala v Regione Siciliana [2011] (Judgement 21 December 2011).

Case C-392/08 European Commission v Kingdom of Spain [2010] ECR I-02537.

Case C-75/08 Christopher Mellor v Secretary of State for Communities and Local Government [2009] ECR I -03799).

Joined cases C-147/06 and C-148/06 SECAP Spa and Santorso Soc. coop. Arl v. Comune di Torino [2008] ECR I-03565.

Case 303/2005 Advocaten voor de Wereld VZW v. Leden van de Ministerraad [2007] ECR I-3633.

Case C-59/00 Ben Mousten Vestergaard v. Spöttrup Boligselskab [2001] ECR I-09505.

Case 222/86 Unectef v. Georges Haylens and others [1987] ECR 04097. 